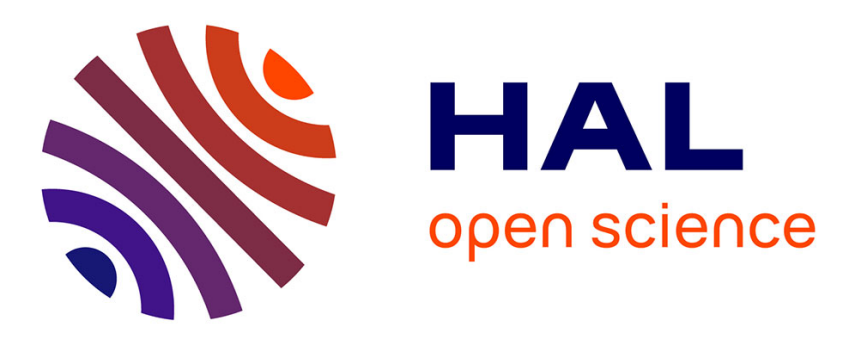

\title{
Reversible dimerization of anion radicals of carbonyl compounds and the electrosynthesis of pinacols. The case of 9-fluorenone
}

\author{
A.S. Mendkovich, A Ngom, V.A. Kokorekin, M.N. Mikhailov, D. \\ Gningue-Sall, V. Jouikov
}

\section{To cite this version:}

A.S. Mendkovich, A Ngom, V.A. Kokorekin, M.N. Mikhailov, D. Gningue-Sall, et al.. Reversible dimerization of anion radicals of carbonyl compounds and the electrosynthesis of pinacols. The case of 9-fluorenone. Electrochimica Acta, 2020, 358, pp.136903. 10.1016/j.electacta.2020.136903 . hal02932013

\section{HAL Id: hal-02932013 \\ https://hal.science/hal-02932013}

Submitted on 10 Sep 2020

HAL is a multi-disciplinary open access archive for the deposit and dissemination of scientific research documents, whether they are published or not. The documents may come from teaching and research institutions in France or abroad, or from public or private research centers.
L'archive ouverte pluridisciplinaire HAL, est destinée au dépôt et à la diffusion de documents scientifiques de niveau recherche, publiés ou non, émanant des établissements d'enseignement et de recherche français ou étrangers, des laboratoires publics ou privés. 
Reversible dimerization of anion radicals of carbonyl compounds and the electrosynthesis of pinacols. The case of 9-fluorenone

Andrey S. Mendkovich, ${ }^{a}$ Arona Ngom, ${ }^{b, c}$ Vladimir A. Kokorekin, ${ }^{a}$ Mikhail N. Mikhailov, ${ }^{a}$ Diariatou Gningue-Sall, ${ }^{b}$ Viatcheslav Jouikov ${ }^{c}$

a N. D. Zelinsky Institute of Organic Chemistry, Russian Academy of Sciences, 119991 Moscow, Russian Federation. Fax: +7 499135 5328; e-mail: asm@free.net

b LCPOAI, Chemistry department, University Cheikh Anta DIOP of Dakar, BP5005 Dakar, Senegal

${ }^{\mathrm{c}}$ UMR 6226 - ISCR, University of Rennes 1, 35042 Rennes, France

\section{Graphical abstract}

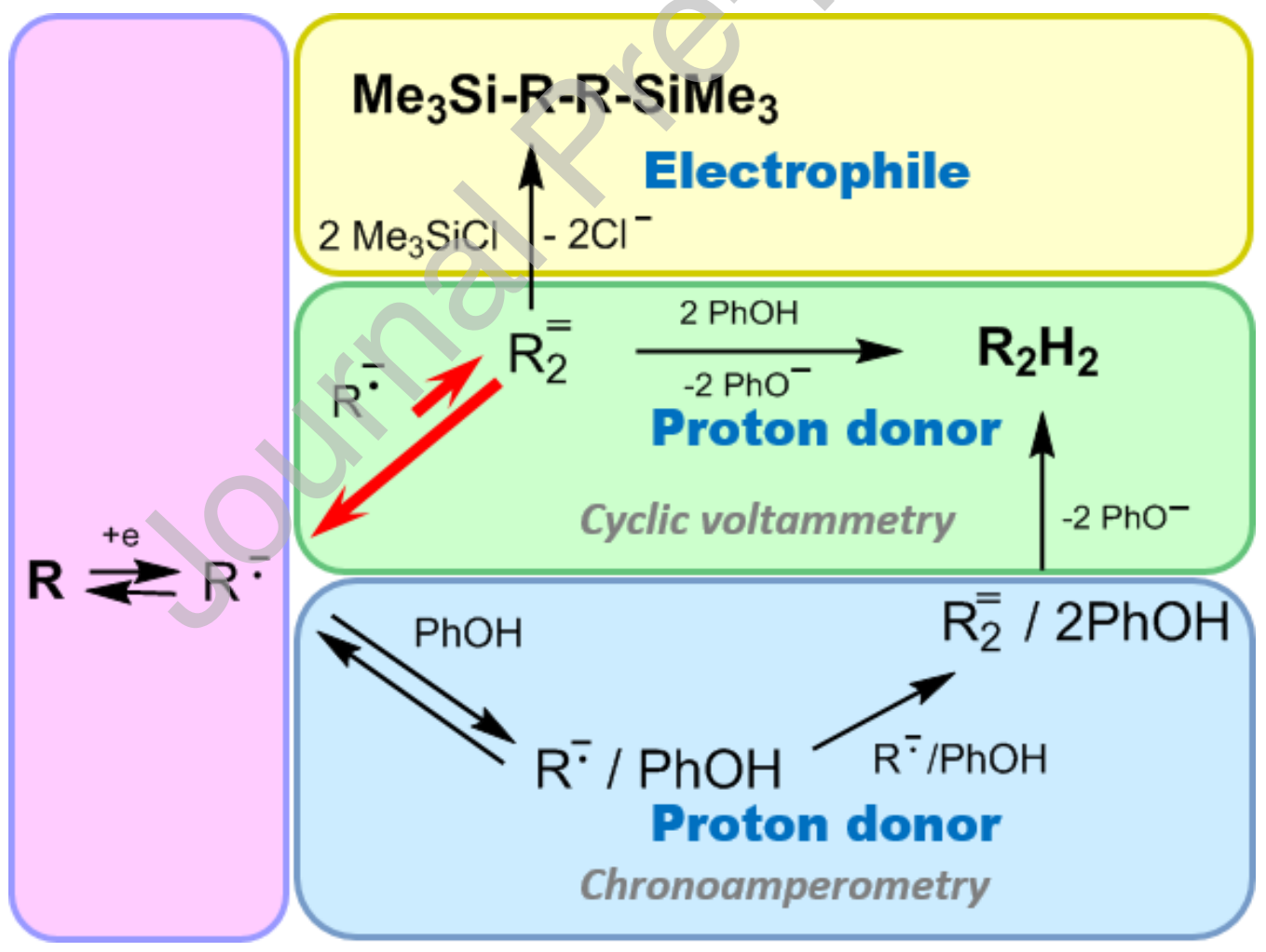




\section{ABSTRACT}

Reversible dimerization of the anion radicals of carbonyl compounds was studied by cyclic voltammetry, chronoamperometry, electrolysis, digital simulation and quantum chemical calculations using electroreduction of 9-fluorenone in DMF/0.1 $\mathrm{M} \mathrm{Bu}_{4} \mathrm{NClO}_{4}$ as an example. The experimental data confirmed that this reaction is thermodynamically unfavorable as it was predicted by DFT calculations. In contrast with some other anion radicals, neither ion pairing of 9-fluorenone anion radicals with lithium cation nor their hydrogen bonding with water shifts the dimerization equilibrium to the dimeric product. Reversibility of the dimerization decreases in the presence of phenol due to the protonation of the dimeric dianion and to the irreversibility of dimerization of the anion radical - phenol complexes. The contribution of these two pathways to general hydrodimerization process is discussed.

Keywords anion radical, dimerization, cyclic voltammetry, chronoamperometry, digital simulation 


\section{Introduction}

Reductive dimerization of carbonyl compounds, first reported back in the mid-19 ${ }^{\text {th }}$ century [1] (1859), is still of great actuality. One of the most interesting modern realizations of this method is electrochemical hydrodimerization of carbonyl compounds which attracts the interest as a "metal-free" process. Note that along with the processes of intermolecular electrodimerization, the examples of analogous reactions leading to vicinal cyclic diols were also reported $[2,3]$.

Along with the great majority of works dealing with the mechanism of electrodimerization of carbonyl compounds in buffered solutions, there are also several reports on the study of this process in aprotic media and with the cations of supporting electrolyte that are not prone to the formation of close ion pairs with the anions (e.g. Alk $\mathrm{N}^{+}$cations); this allows one to exclude the influence of these factors on electronic structure of the anion radicals and, in particular, on spin and charge distribution in these species. This permitted to reveal the relationship of the fundamental parameters of electronic structure, determined by means of quantum chemistry, with the reactivity of the anion radicals (in particular, with the rates of their dimerization $[6,10$, $13-15])$, including the cases when different reaction centers are involved $[11,13,15]$. Besides, general equations were derived relating rate constants of the formation of dimeric products in the reactions between two anion radicals, between an anion radical and a starting molecule, or between a dianion and a neutral molecule, etc [13 - 15]. The issues of reversibility of dimerization of the anion radicals of carbonyl compounds were addressed less often, which is probably related to the fact that this process has irreversible character because of the formation of a $\mathrm{C}-\mathrm{C}$ bond $[2-12]$. At the same time, one can suppose that the anion radicals of carbonyl compounds showing no tendency to coupling can, in fact, be involved in a reversible dimerization whose the equilibrium is shifted towards the monomers. In order to test this hypothesis, 9-fluorenone (1) was taken as a model because it forms a remarkably persistent anion radical $\left(\mathbf{1}^{*}\right)[16,17]$. The preference of $\mathbf{1}$ also relies on the fact that the electrochemical behavior 
of its reduction products, 9-fluorenol [18] and 9H,9'H-bifluorene-9,9'-diol (2) [19] (Scheme 1) has been studied previously in detail.

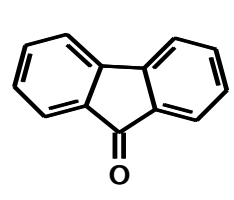

1

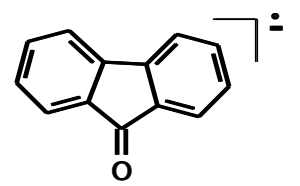

$1^{\bullet-}$

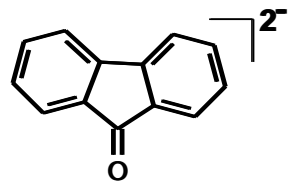

$1^{2}$

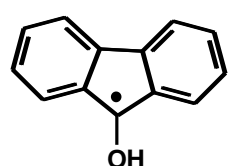

$3 \cdot$

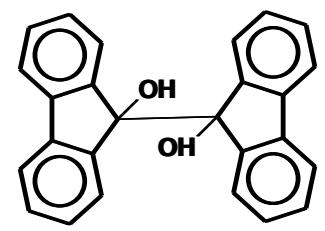

2

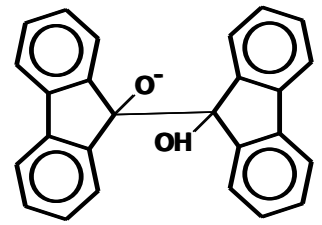

2-

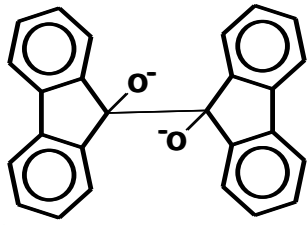

$2^{2}-$

Scheme 1. Structures and designations of the compounds and intermediates studied

\section{Experimental}

\subsection{General.}

9H-Fluoren-9-one (1), phenol, $\left(\mathrm{CH}_{3}\right)_{3} \mathrm{SiCl},\left(\mathrm{CH}_{3}\right)_{2} \mathrm{SiCl}_{2}, \mathrm{Bu}_{4} \mathrm{NClO}_{4}, \mathrm{Bu}_{4} \mathrm{NPF}_{6}, \mathrm{DMF}$ and $\mathrm{MeCN}$ ("extra dry" grade) were supplied by Acros Organics. ${ }^{1} \mathrm{H}$ and ${ }^{13} \mathrm{C}$ NMR spectra of the products in $\mathrm{CDCl}_{3}$ were recorded on a Bruker Avance 300 instrument $\left(300.13 \mathrm{MHz}\right.$ for ${ }^{1} \mathrm{H}$ and $75.47 \mathrm{MHz}$ for ${ }^{13} \mathrm{C}$ ). The chemical shifts values $(\delta)$ are expressed relative to the chemical shifts of the solvent-d or TMS as an internal standard. FT-IR spectra were recorded using a Frontier Optica FTIR spectrophotometer (Perkin-Elmer). GC-MS was done at an HP-5973 MSD (EI mode, 70 $\mathrm{kV}$, Agilent Technologies) station fitted with a $0.25 \mathrm{~mm} \times 30 \mathrm{~m}$ capillary column (OPTIMA-240, Mackerel-Nägel). The X-Ray structure was obtained using a D8 VENTURE Bruker AXS diffractometer equipped with a (CMOS) PHOTON 100 detector, Mo-K $\alpha$ radiation $(\lambda=0.71073$ $\AA$, multilayer monochromator). The structure was solved by dual-space algorithm using the SHELXT program and then refined with full-matrix least-squares methods based on $F^{2}$ (SHELXL) [20]. All non-hydrogen atoms were refined with anisotropic atomic displacement 
parameters. $\mathrm{H}$ atoms were finally included in their calculated positions and treated as riding on their parent atom with constrained thermal parameters. A final refinement on $F^{2}$ with 9939 unique intensities and 493 parameters converged at $\omega R_{F}^{2}=0.1848\left(R_{F}=0.0739\right)$ for 7396 observed reflections with $I>2 \sigma(I)$.

\subsection{Electroanalytical and electrolysis instrumentation, experimental techniques}

Chronoamperometry (CA) and cyclic voltammetry (CV) were implemented using a computerassisted potentiostat P-30JM (Elins, Russia) (scan rate error $0.095 \%$, potential setting \pm 3000 $\mathrm{mV})$. The experiments were performed in a glass electrochemical cell fitted with a water jacket for thermostating. Polarization curves were recorded in a three-electrode configuration. All electrodes were homemade. A glassy-carbon disc electrode $(d=1.7 \mathrm{~mm})$ was used as the working electrode. The electrode surface was polished with chromium oxide paste $(8-17 \mu \mathrm{m})$ and the solution was agitated vigorously with argon before recording each CA and CV curve. A platinum plate $\left(S=3 \mathrm{~cm}^{2}\right)$ served as the auxiliary electrode. A saturated calomel electrode (SCE) was used as the reference electrode and was connected to the solution by a bridge with a porous glass frit diaphragm filled with the supporting electrolyte $\left(0.1 \mathrm{M} \mathrm{Bu}_{4} \mathrm{NClO}_{4}\right.$ solution in $N, N$ dimethylformamide (DMF)). Under the conditions used, the potential of ferrocenium / ferrocene redox pair $v s$ SCE was stable and equal to $+0.468 \pm 0.005 \mathrm{~V}$. The solutions to be tested were thermostated at $25 \pm 0.5^{\circ} \mathrm{C}$ and deaerated by bubbling argon. To prevent any contact between the solution and the ambient air during the experiment, argon was continuously fed into the cell above the solution surface.

For $\mathrm{CA}$ and $\mathrm{CV}$ curves analyses, the current values in the presence of the substrate were corrected for the current of the supporting electrolyte at the given potential. The concentrations of fluorenone $1\left(C_{1}\right)$ and phenol $\left(C_{\mathrm{PhOH}}\right)$ ranged from 5 to $30 \mathrm{mmol} \mathrm{L} \mathrm{L}^{-1}$ and the potential scan rates $(v)$ varied from 0.016 to $5 \mathrm{~V} \mathrm{~s}^{-1}$. The sampled current voltammograms [21] (a subtype of steady-state voltammograms [22]) were plotted using the values of the current from the CA curves at a transient time $(t)$ of $2 \mathrm{~s}$ at the corresponding potentials. Cathodic $\left(i_{1 \mathrm{c}}\right)$ and anodic $\left(i_{1 \mathrm{a}}\right)$ 
peak currents and cathodic $\left(i_{\mathrm{c}}\right)$ and anodic $\left(i_{\mathrm{a}}\right)$ currents at $t=2 \mathrm{~s}$ and $t=4 \mathrm{~s}$ were used as the response functions in the case of $\mathrm{CV}$ and double step $\mathrm{CA}$, respectively. The uncompensated resistance $\left(R_{\mathrm{u}}=400 \pm 15 \Omega\right)$ and active area of working electrode $\left(0.067 \mathrm{~cm}^{2}\right)$ were determined by the procedure described earlier [23].

Electrolysis was carried out in a glass temperature-controlled $\left(20-25^{\circ} \mathrm{C}\right)$ divided cell $(V=70$ $\mathrm{mL})$ equipped with trace-paper diaphragm and plane glassy carbon electrodes $\left(S_{\text {cathode }}=8 \mathrm{~cm}^{2}\right.$, $\left.S_{\text {anode }}=4 \mathrm{~cm}^{2}\right) .9 H$-fluoren-9-one $1(0.72 \mathrm{~g}, 4 \mathrm{mmol})$ and phenol $(0.85 \mathrm{~g}, 9 \mathrm{mmol})$ were dissolved in $0.1 \mathrm{M}$ solution of $\mathrm{Bu}_{4} \mathrm{NClO}_{4}$ in $\mathrm{DMF}(55 \mathrm{~mL})$ and placed into the cathodic compartment of the cell. The anodic compartment contained $0.1 \mathrm{M}$ solution of $\mathrm{Bu}_{4} \mathrm{NClO}_{4}$ in DMF $(15 \mathrm{~mL})$. The process was performed with vigorous stirring under argon atmosphere at the cathodic potential of $-1.35 \mathrm{~V}$ to full conversion of fluorenone 1 (monitored by TLC) and current $\sim 5 \mathrm{~mA}$. After the end of electrolysis, water $(\sim 100 \mathrm{~mL})$ was added to the catholite and the formed yellowish precipitate was filtered off. The filtrate was extracted by $\mathrm{Et}_{2} \mathrm{O}(3 \times 50 \mathrm{~mL})$. The extracts were dried over anhydrous $\mathrm{Na}_{2} \mathrm{SO}_{4}$, then concentrated in vacuo and combined with first collected precipitate. The subsequent purification of the resulting crude by column chromatography (Silica gel $0.035-0.070 \mathrm{~mm}, 60 \AA$; eluent - light petroleum-EtOAc) gave pure 9H,9'H-[9,9'-bifluorene]-9,9'-diol 2 (0.54 g, 75\% yield): m.p. $180-182{ }^{\circ} \mathrm{C} ;{ }^{1} \mathrm{H}$ NMR $\delta: 5.57$ (s, $2 \mathrm{H}, \mathrm{OH}), 7.29-7.46(\mathrm{~m}, 8 \mathrm{H}, \mathrm{Ph}), 7.61-7.71(\mathrm{~m}, 8 \mathrm{H}, \mathrm{Ph})$. Anal. calcd for $\mathrm{C}_{26} \mathrm{H}_{18} \mathrm{O}_{2}(\%): \mathrm{C}$ 86.16, H 5.01; found: C 85.95, H 5.00.

In order to avoid the interference of $\mathrm{ClO}_{4}{ }^{-}$with chlorosilanes during the electrolysis because of high oxophilicity of $\mathrm{Si}$, the reduction of fluorenone $\mathbf{1}$ in the presence of $\left(\mathrm{CH}_{3}\right)_{3} \mathrm{SiCl}$ and $\left(\mathrm{CH}_{3}\right)_{2} \mathrm{SiCl}_{2}$ was carried out using $\mathrm{Bu}_{4} \mathrm{NPF}_{6}$ supporting electrolyte instead of perchlorate. Since chlorosilanes are extremely prone to hydrolysis by the residual water in the solution releasing protons that can alter the reduction mechanism, the target electrolysis was preceded by an in-situ electrolytic drying the catholyte [24]. For this, $\left(\mathrm{CH}_{3}\right)_{3} \mathrm{SiCl}(0.3 \mathrm{mmol}, 32 \mathrm{mg})$ were added to the solution of fluorenone $1(0.81 \mathrm{~g}, 4.5 \mathrm{mmol})$ in $0.2 \mathrm{M} \mathrm{Bu}_{4} \mathrm{NPF}_{6}$ solution in $\mathrm{CH}_{3} \mathrm{CN}(V=50 \mathrm{~mL})$ 
and the mixture was electrolyzed at a slightly negative cathodic potential $(-0.3 \ldots-0.6 \mathrm{~V})$ using an additional Pt electrode $\left(S=8 \mathrm{~cm}^{2}\right)$ in order to reduce the protons formed from the hydrolysis. The product of hydrolysis, hexamethyl disiloxane, is chemically and electrochemically inert and is being evaporated with the solvent during the workup. ${ }^{1}$ After the current of the pre-electrolysis dropped to ca. $5-7 \%$ of its initial value, the necessary amount of the corresponding freshly distilled $\left(\mathrm{CH}_{3}\right)_{3} \mathrm{SiCl}(1.22 \mathrm{~g}, 11.25 \mathrm{mmol})$ or $\left(\mathrm{CH}_{3}\right)_{2} \mathrm{SiCl}_{2}(0.70 \mathrm{~g}, 5.4 \mathrm{mmol})$ was injected via a syringe and the potential was shifted to the $-1.20 \ldots-1.40 \mathrm{~V}$ allowing to maintain current density of $7 \mathrm{~mA} \mathrm{~cm}{ }^{-2}$ till the end of the electrolysis. The electrolysis was stopped after passing $1.2 \mathrm{~F}$ (522 C), acetonitrile was evaporated in vacuo and the resulting yellow solid has been extracted with pentane $(3 \times 20 \mathrm{~mL})$. The concentrating and flash chromatography (Silica gel, $60-65$ mesh, eluent - hexane) gave colorless single crystals (suitable for X-ray diffractometry after slow evaporation of hexane) of 9,9'-bis[(trimethylsilyl)oxy]-9H,9'H-9,9'-bifluorene (0.95 g, 84\%): m.p. $241{ }^{\circ} \mathrm{C}\left(240-241{ }^{\circ} \mathrm{C}[25]\right)$. FT-IR, $\mathrm{cm}^{-1}: 2950 v\left(\mathrm{C}_{\mathrm{sp} 2}-\mathrm{H}\right), 1519,1464 v(\mathrm{C}=\mathrm{C}), 1277$, 1251 (shoulder) $\delta\left(\mathrm{Si}_{-} \mathrm{CH}_{3}\right), 1372,1084,888 v(\mathrm{Si}-\mathrm{O}), 842 v(\mathrm{C}-\mathrm{Si}), 762 v(\mathrm{Si}-\mathrm{H}), 738 \delta\left(\mathrm{C}_{\mathrm{sp} 2}-\mathrm{H}\right)$. ${ }^{1} \mathrm{H}$ NMR, $\delta:-0.29(\mathrm{~s}, 18 \mathrm{H}, \mathrm{Me}), 6.90-7.05$ and $7.19-7.21(\mathrm{~m}, 12 \mathrm{H}, \mathrm{Ph}), 7.31-7.33(\mathrm{~m}, 4 \mathrm{H}$, $\mathrm{Ph}) ;{ }^{13} \mathrm{C}$ NMR $\delta: 1.2\left(\mathrm{Si}\left(\mathrm{CH}_{3}\right)_{3}\right), 88.3\left(C_{\mathrm{sp}^{3}} \mathrm{O}\right), 118.7,126.3,128.5,140.7,145.9 . \mathrm{GC}-\mathrm{MS}, \mathrm{m} / z$ : $506\left(\mathrm{M}^{+}\right), 491\left(\mathrm{M}^{+}-\mathrm{Me}\right), 433\left(\mathrm{M}^{+}-\mathrm{TMS}\right), 417\left(\mathrm{M}^{+}-\mathrm{TMSO}\right), 328\left(\mathrm{M}^{+}-2 \mathrm{TMSO}\right), 253$ $\left(\mathrm{M}^{+} / 2\right), 180\left(\mathrm{M}^{+} / 2-\mathrm{TMS}\right), 73(\mathrm{TMS})$.

\subsection{Digital simulations}

Digital simulations of CA and CV curves were carried out using DigiElch Professional, version 8F (Build 8.222), from ElchSoft. Computation of the model curves was performed taking into account the edge effect and solution uncompensated resistance. The rate constants were determined from $\mathrm{CA}$ and $\mathrm{CV}$ data using the procedure described previously $[22,18,26]$ that

\footnotetext{
${ }^{1}$ When using $\left(\mathrm{CH}_{3}\right)_{2} \mathrm{SiCl}$ for drying the solution of $\left(\mathrm{CH}_{3}\right)_{2} \mathrm{SiCl}_{2}$, the remnants of non-hydrolyzed $\left(\mathrm{CH}_{3}\right)_{2} \mathrm{SiCl}$ account for the formation of some amount of di-trimethylsilylated product, attesting to higher efficiency of O-silylation with $\left(\mathrm{CH}_{3}\right)_{2} \mathrm{SiCl}$ compared to $\left(\mathrm{CH}_{3}\right)_{2} \mathrm{SiCl}_{2}$.
} 
involved the variation of kinetic parameter $\lambda[27,28]$, defined as $\lambda=R T C_{\mathrm{PhOH}} C_{1} / F v$ and $\lambda=$ $C_{\mathrm{PhOH}} C_{1} t$ for $\mathrm{CV}$ and $\mathrm{CA}$, respectively.

The diffusion coefficient $D$ of compound 1 in DMF was taken as $10^{-5} \mathrm{~cm}^{2} \mathrm{~s}^{-1}$, based on the value found earlier for 1 [29]. The values of $D$ for $\mathbf{2}$ and for hydrogen-bonded complex of $\mathbf{1}$, whose molecular volumes are approximately 2 and 1.5 times larger than that of $\mathbf{1}$, were estimated using the equation [30] as $7 \cdot 10^{-6} \mathrm{~cm}^{2} \mathrm{~s}^{-1}$ and $8 \cdot 10^{-6} \mathrm{~cm}^{2} \mathrm{~s}^{-1}$, respectively. The diffusion coefficients in DMF-water mixtures were estimated using the values of the viscosities from [31]. The $D$ of ions and the corresponding neutral species were taken equal [32].

Thus chosen values permitted to achieve a good agreement between the experimental and the theoretical peak currents in the entire range of concentrations and potential scan rates studied. Electron transfer reaction (1) was considered to be fast and reversible. The values of the transfer coefficients $(\alpha)$ were taken as 0.5 . Proton transfer reactions $(4,5)$ and $(9)$ were considered to be fast and irreversible. Simulation of fast heterogeneous reactions was performed using the default values of the rate constants of electron transfer $\left(k_{s}=10^{4} \mathrm{~cm} \mathrm{~s}^{-1}\right)$, as implemented in the software. In the case of homogeneous processes, the rate constants of fast reactions were taken as an average value of diffusion-controlled rate constants in DMF, $4 \cdot 10^{9} \mathrm{M}^{-1} \mathrm{~s}^{-1}$ [33]. Standard potentials $\left(E^{0}\right)$ and homogeneous equilibrium and rates constants were determined using standard DigiElch Professional techniques optimizing the model curves to best fit with the experimental ones over the ranges of scan rates and concentrations indicated above with subsequent determination of the average values. The best agreement between the simulated and the experimental response functions was obtained for the following set of simulation parameters: $E_{1}^{0}$ $=-1.25 \mathrm{~V}, K_{7}=1.1 \mathrm{M}^{-1}, k_{7} \geq 1 \cdot 10^{4} \mathrm{M}^{-1} \mathrm{~s}^{-1}$ in the case of $\mathrm{CV}$, and $K_{3}=5 \cdot 10^{-6} \mathrm{M}^{-1}, k_{3} \geq 1 \cdot 10^{6} \mathrm{M}^{-1} \mathrm{~s}^{-}$

${ }^{1}$ in the case of CA. Variation of $k_{3}$ and $k_{7}$ above the indicated values does not affect the response function.

\subsection{Quantum chemical calculations}


The quantum chemical calculations were performed in the framework of density functional theory (DFT) with B3LYP exchange correlation functional [34 - 36] using Gaussian 03 [37] and Gaussian 09 [38] program packages. As we have shown earlier [39], the calculated energies of the anion radicals of the compounds with $\pi$-bonds significantly depend on the inclusion of diffuse functions on hydrogen atoms in the basis set, whereas these effects are insignificant for the compounds without $\pi$-bonds. Therefore, all calculations in this work were performed using 6$311++\mathrm{G}(\mathrm{d}, \mathrm{p})$ basis set. Geometry optimization was done for all species considered. The nature of the stationary points (a minimum or a saddle point on the potential energy surface) was determined calculating the eigenvalues of the matrix of second derivatives of energy with respect to nuclear coordinates. In all optimizations, solvatation was taken into account within the reactive field continuum models: PCM [40 - 42] and CSC-PCM [43] using the parameters for DMSO, which are similar to those of DMF used in the experiments.
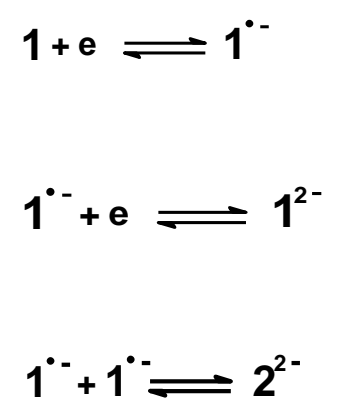

\section{Results and discussion}

Cyclic voltammograms of $\mathbf{1}$ in $\mathrm{DMF} / 0.1 \mathrm{M} \mathrm{Bu}_{4} \mathrm{NClO}_{4}$ (Fig. 1) exhibit two cathodic peaks, first of which is related to the formation of an anion radical $\left(\mathbf{1}^{-}\right)$, while the second one corresponds to the formation of a dianion $\left(\mathbf{1}^{2-}\right)[16,17]$. From the ratio of first cathodic peak current $\left(i_{1 \mathrm{c}}\right)$ to the theoretical value of diffusion current of a one-electron process, the apparent number of electrons $\left(n_{\mathrm{app}}\right)$ was found to be $1.02 \pm 0.02$ over the whole interval of concentrations of $\mathbf{1}$ and the scan rates considered. 


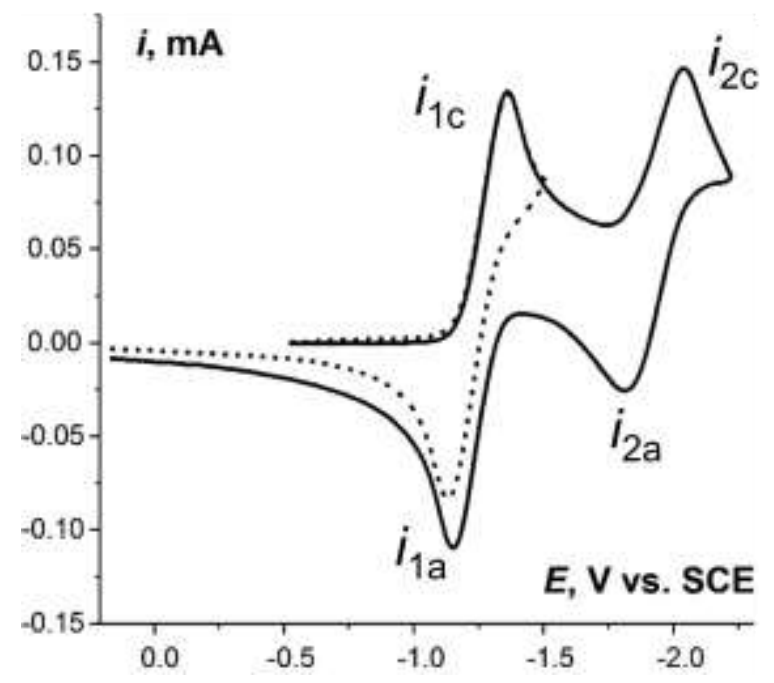

Figure 1. Cyclic voltammograms of $1\left(7 \mathrm{mmol} \mathrm{L}^{-1}\right)$ in $\mathrm{DMF} / 0.1 \mathrm{M} \mathrm{Bu}_{4} \mathrm{NClO}_{4}$ at the potential scan rate of $0.1 \mathrm{~V} \mathrm{~s}^{-1}$.

As is seen from Fig. 2, the process occurring at the potentials of the first reduction peak is chemically reversible even at high values of $c_{1}$ and at slow scan rates $v$ : the experimental parameter $i_{1 \mathrm{a}} / i_{1 \mathrm{c}}$ corresponds to its theoretical value for a diffusion-controlled process noncomplicated by chemical reactions in the near-electrode layer.

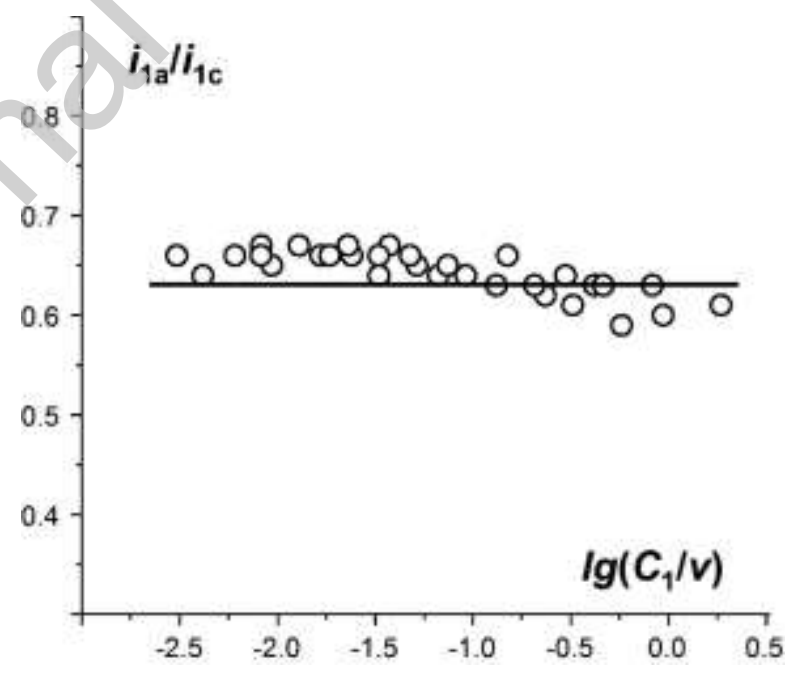

Figure 2. Experimental (circles) and simulated for the diffusion-controlled process (line) dependences of $i_{1 \mathrm{a}} / i_{1 \mathrm{c}}$ on $\boldsymbol{C}_{1}$ and $v^{-1}$.

One-electron nature of the process and its chemical reversibility are also attested by chronoamperometry. Fig. 3 features a voltammogram plotted using the CA data. The limiting 
cathodic currents of these curves increases linearly with $C_{1}$ and corresponds to the observed electron stoichiometry $\left(n_{\text {app }}=1.02 \pm 0.03\right)$, while anodic-to-cathodic current ratio at $t=2$ and $4 \mathrm{~s}$ $(0.290 \pm 0.005)$ is independent on $C_{1}$ and is close to the theoretical value for a diffusioncontrolled process (Fig. 4).

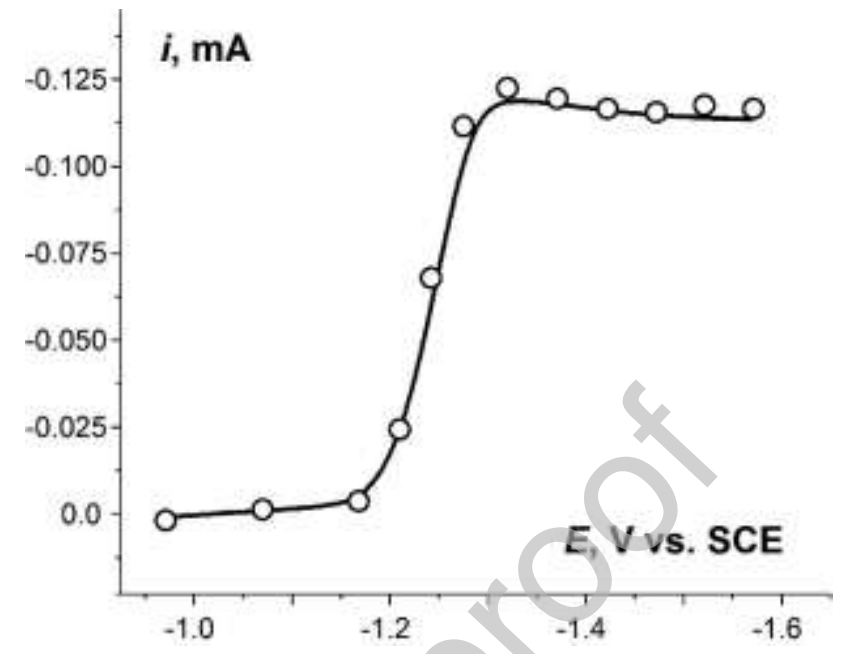

Figure 3. Experimental CA currents ( $2 \mathrm{~s}$ after applying the potential pulse) of $\mathbf{1}\left(10 \mathrm{mmol} \mathrm{L}^{-1}\right)$ in $\mathrm{DMF} / 0.1 \mathrm{M} \mathrm{Bu}_{4} \mathrm{NClO}_{4}$ solution (circles) and the simulated curve (line).

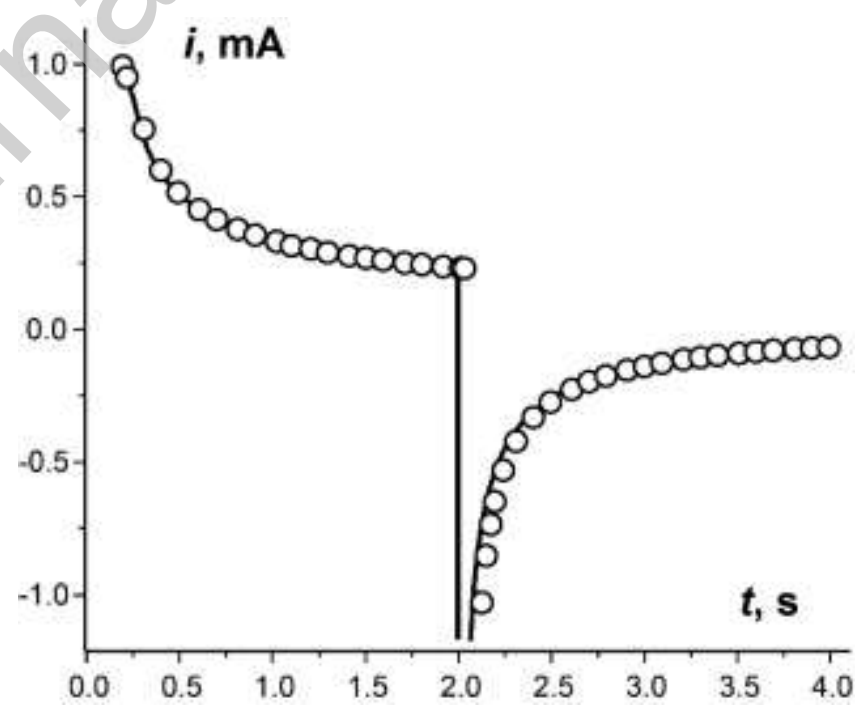

Figure 4. CA curves of $1\left(20 \mathrm{mmol} \mathrm{L}^{-1}\right)$ in $\mathrm{DMF} / 0.1 \mathrm{M} \mathrm{Bu}_{4} \mathrm{NClO}_{4}$ at the limiting current potentials: experimental (line) and simulated (circles). 
These results might be considered as a formal indication that the anion radical $\mathbf{1}^{*}$ does not show any detectable reactivity under the conditions given. However, experimental data on the reactivity of anion radicals of aromatic carbonyl compounds under similar conditions [4 - 12] and the corresponding theoretical considerations [6, 10, $13-15]$ imply that the possibility of dimerization of $1^{*-}$ cannot be ruled out. In particular, the rate of dimerization of the anion radicals was shown to correlate with the spin density on the reaction center [13 - 15]. Quantum chemical analysis of the spin density on carbon atom of the carbonyl group in $\mathbf{1}^{*-}$ shows it to be 0.25 . From the correlation of $k_{3}$ with the spin density $[14,15]$, the rate constant of dimerization of $1^{*-}$ was estimated as $10^{4} \mathrm{M}^{-1} \mathrm{~s}^{-1}$. Therefore, we supposed reaction (3) to be reversible, with equilibrium shifted towards $\mathbf{1}^{*}$. This hypothesis is in agreement with the results of quantum chemical calculations providing positive free enthalpy of reaction (3), $\Delta \mathrm{G}=62.3 \mathrm{~kJ} \mathrm{~mol}^{-1}$.

The interactions with media components strongly affect kinetics and thermodynamics of the reactions of ion radicals for they modify the electronic structure of these species $[11,15,44,45]$. When the anion radicals of carbonyl compounds are involved in ion pairing, spin density on the atoms of their carbonyl group increases [45, 46], which in turn increases the rate of their radical dimerization $[14,15]$. In addition, stabilization of dimer dianions by ion pairing is favorable for reducing the degree of reversibility of dimerization, as was previously observed for several acetyl derivatives [5] and activated olefins [47]. Since the influence of a cation increases when it decreases in size [44], the behavior of $\mathbf{1}$ has been scrutinized in lithium perchlorate solutions.

The addition of $\mathrm{LiClO}_{4}$ to the solution of $\mathbf{1}$ does not affect electron stoichiometry of the process at the first peak and the number of electrons at this step remains unchanged, $n_{\text {app }}=1.01 \pm 0.02$. Instead, a new peak emerges at slightly more negative potentials, whose current grows as the concentration of $\mathrm{Li}^{+}$increases (Fig. 5). Concomitantly, the current of the reduction of $\mathbf{1}^{{ }^{--}}$to $\mathbf{1}^{2-}$ $\left(i_{2 \mathrm{c}}\right)$ decreases, though its chemical reversibility is maintained as is attested by the invariance of the $i_{2 \mathrm{a}} / i_{2 \mathrm{c}}$ ratio. In $\mathrm{DMF} / 0.1 \mathrm{M} \mathrm{LiClO}_{4}$ solution, with $\mathrm{LiClO}_{4}$ as the sole electrolyte, only the abovementioned new peak remains on the voltammograms (Fig. 5). The emergence of a new 
peak on the voltammograms of carbonyl compounds upon the addition of a lithium salt was observed previously and was rationalized as the formation of ion pairs between anion radicals and $\mathrm{Li}^{+}$[48]. However, unlike acetyl derivatives of arenes [5] for which chemical reversibility of the first reduction step decreases when increasing $\mathrm{Li}^{+}$concentration, the addition of $\mathrm{LiClO}_{4}$ up to 4-fold excess does not alter the ratio of anodic to cathodic peaks of $1\left(i_{1 \mathrm{a}} / i_{1 \mathrm{c}}=0.63 \pm 0.01\right)$ if the vertex potential does not exceed $-1.70 \mathrm{~V}$. Taking into account that in the case of $\mathbf{1}$ the addition of $\mathrm{LiClO}_{4}$ practically does not affect the first peak, it should be assumed that the appearance of a new peak is caused by the formation of ion pairs $\mathrm{Li}^{+}$with $\mathbf{1}^{2-}$. The absence of any visible influence of $\mathrm{Li}^{+}$on the dimerization of $\mathbf{1}^{-*}$ and on its equilibrium constant $\left(K_{3}\right)$ can be rationalized that $\mathbf{1}^{\cdot-}$ and $\mathbf{2}^{2-}$ are equally stabilized by the association with $\mathrm{Li}^{+}$cations.

\section{$2^{2-}+\mathrm{HB} \longrightarrow 2^{-}+\mathrm{B}^{-}$}

\section{$2^{-}+\mathrm{HB} \longrightarrow 2+\mathrm{B}^{-}$}

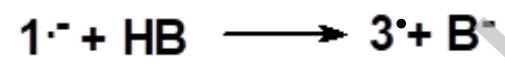

An alternative way for preventing dissociation of the dimer dianion might be protonating it by an appropriate proton donor. Expectedly, a pinacol can be obtained from the reduction of $\mathbf{1}$ in aprotic solvents in the presence of proton donors capable of protonating $\mathbf{2}^{\mathbf{2}-}$ and $\mathbf{2}^{-}$(reactions 4 and 5) but not $\mathbf{1}^{-}$(reaction 6). The results of quantum chemical calculations show water and phenol to meet this requirement (Table 1). 


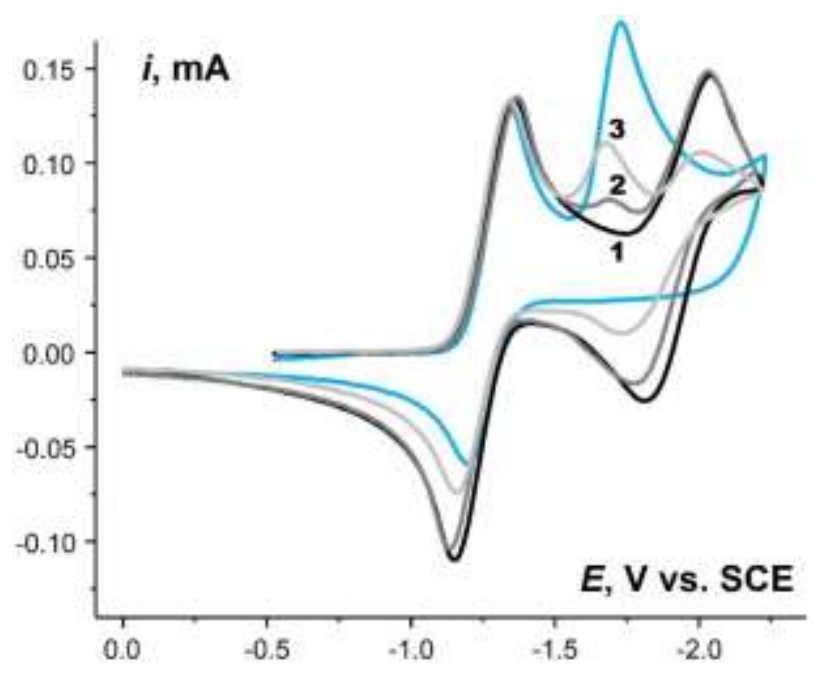

Figure 5. Cyclic voltammograms of $1\left(7 \mathrm{mmol} \mathrm{L}^{-1}\right)$ in $\mathrm{DMF} / 0.1 \mathrm{M} \mathrm{Bu}_{4} \mathrm{NClO}_{4}$ in the presence of $0(1), 3.5$ (2) and $10.0(3) \mathrm{mmol} \mathrm{L}^{-1} \mathrm{LiClO}_{4}$. Blue curve: $1\left(7 \mathrm{mmol} \mathrm{L}^{-1}\right)$ in $\mathrm{DMF} / 0.1 \mathrm{M} \mathrm{LiClO}_{4}$. Scan rate $v=0.1 \mathrm{~V} \mathrm{~s}^{-1}$.

Table 1. Gibbs free energy $\left(\mathrm{kJ} \mathrm{mol}^{-1}\right)$ for protonation reactions (from DFT B3LYP/6-3$11++G(d, p)$ CSC-PCM).

\begin{tabular}{|l|l|l|}
\hline \multirow{2}{*}{ Reaction } & \multicolumn{2}{|l|}{ Proton donor $\mathrm{HB}$} \\
\cline { 2 - 3 } & $\mathrm{H}_{2} \mathrm{O}$ & $\mathrm{PhOH}$ \\
\hline 4 & -25.0 & -101.8 \\
\hline 5 & 55.7 & -21.1 \\
\hline 6 & 141.2 & 64.4 \\
\hline
\end{tabular}

The addition of up to $20 \%$ water to the solution does not lead to the appearance of any new peaks on the voltammograms of $\mathbf{1}$ and only causes the $i_{2 \mathrm{a}} / i_{2 \mathrm{c}}$ ratio to decrease due to the protonation of dianion of 1 by water [17]. First reduction step keeps a one-electron character $\left(n_{\text {app }}=1.06 \pm\right.$ $0.04)$, while the $i_{1 \mathrm{a}} / i_{1 \mathrm{c}}$ ratio is still that typical of diffusion-controlled processes. Therefore, one might state that under these conditions the proton-donor ability of water - as expected from the quantum chemical calculations (Table 1) - is insufficient for irreversible protonation of the 
dimer dianion. Furthermore, the rate of formation of the dimeric products does not increase as in case of activated olefins [28].

The irreversibility of dimerization can be achieved with phenol as a proton donor. In DMF, the $\mathrm{pK}_{\mathrm{a}}$ of phenol is 14 orders of magnitude lower than that of water [49] and unlike water, phenol greatly affects chemical reversibility of the first step of reduction of $\mathbf{1}$. Increasing the concentration of phenol causes the depletion of the anodic peak $i_{1 \mathrm{a}}$ (Fig. 6) along with the appearance of the oxidation signal of phenolate anion at positive potentials; this anodic peak grows as the $\left(C_{\mathrm{PhOH}} / C_{1}\right)$ ratio increases. Meanwhile, just as in the case with water, the oneelectron level of first reduction peak remains unchanged $\left(n_{\text {app }}=1.01 \pm 0.03\right)$ up to a 6 -fold excess of phenol. This observation, as well as the data of Table 1, suggest that the acidity of phenol is insufficient for reaction (6) to run with a noticeable rate. Otherwise, the process would follow an ECE mechanism with the increased number of electrons involved, because quantum mechanical calculations have shown electron affinity of $\mathbf{3}(3.39 \mathrm{eV})$ to be higher than that of $\mathbf{1}$ $(3.19 \mathrm{eV})$.

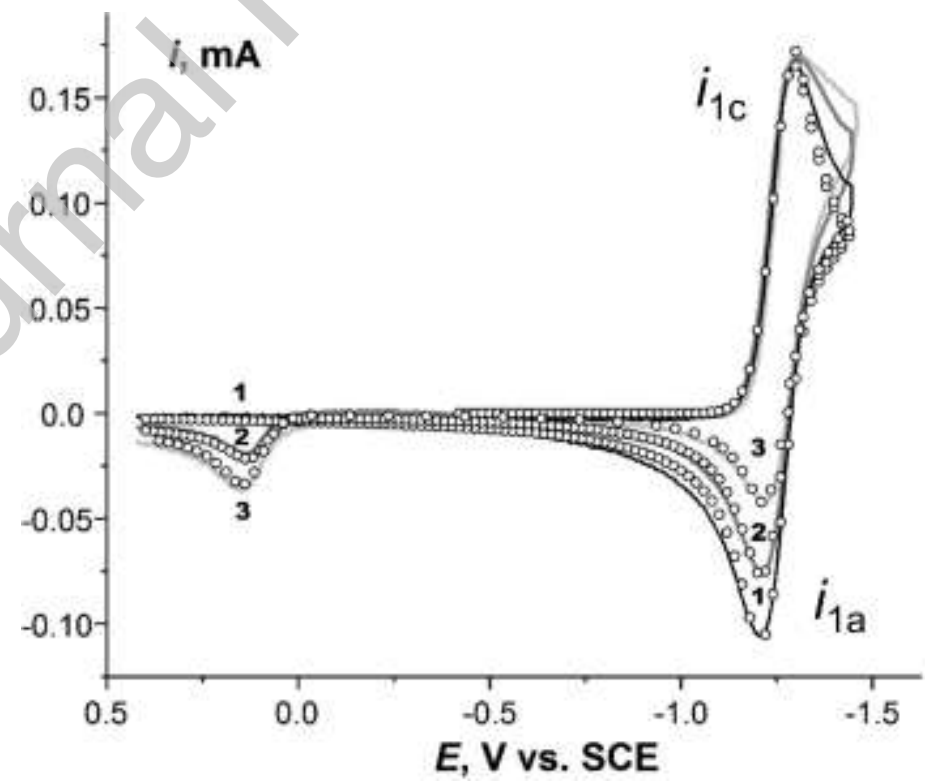

Figure 6. Cyclic voltammograms of $1\left(10 \mathrm{mmol} \mathrm{L}^{-1}\right)$ in $\mathrm{DMF} / 0.1 \mathrm{M} \mathrm{Bu}_{4} \mathrm{NClO}_{4}$ at $v=0.1 \mathrm{~V} \mathrm{~s}^{-1}$ in the presence of $0(1), 5(2)$ and $15(3) \mathrm{mmol} \mathrm{L}^{-1}$ of phenol (lines), and simulated curves (circles) for mechanism (1, 7 - 9). For simulation parameters see Section 2.3. 
The ratio of anodic to cathodic currents in CA at the potential of limiting current of the first peak (at $t=2$ and $4 \mathrm{~s}$, respectively), as well as the ratio of peak currents in CV both decrease reciprocating the increase in $C_{\mathrm{PhOH}} / C_{1}$ (Fig. 7). Both methods thus attest that first reduction step of $\mathbf{1}$ in the presence of $\mathrm{PhOH}$ becomes irreversible leading to the formation of $\mathbf{2}$. Although the large scale electrolysis of $\mathbf{1}$ at the limiting current potential with the addition of phenol in fact gave pinacol 2 as a main product (75\% yield, see Experimental), there is still an uncertainty regarding the exact pathway of this process.

Comparing the data of CA with the results of digital simulation (Fig. 7), one might conclude that the electroreduction of $\mathbf{1}$ under these conditions follows the mechanism including reactions $(1,3$ -5). However, the dependencies $i_{1 \mathrm{a}} / i_{1 \mathrm{c}}$ vs. $C_{\mathrm{PhOH}} / C_{1}$ (Fig. 8) from cyclic voltammetry differ from what was expected for this mechanism. Equilibrium constants $K_{3}$ obtained for the mechanism (1, $3-5)$ are changing by almost two orders of magnitude depending on the value of $C_{\mathrm{PhOH}} / C_{1}$. Remembering of the proneness of $\mathrm{PhOH}$ to form hydrogen bonds [50], we considered an alternative mechanism $(1,7-9)$, which was previously observed during electroreduction of activated olefins $[28,51]$. This mechanism is supported by the appearance of a new reduction peak at $-1.55 \mathrm{~V}$ in the presence of phenol; this peak supposedly accounts for the reduction of a hydrogen-bonded complex of $\mathbf{1}^{*-}$ with $\mathrm{PhOH}$.

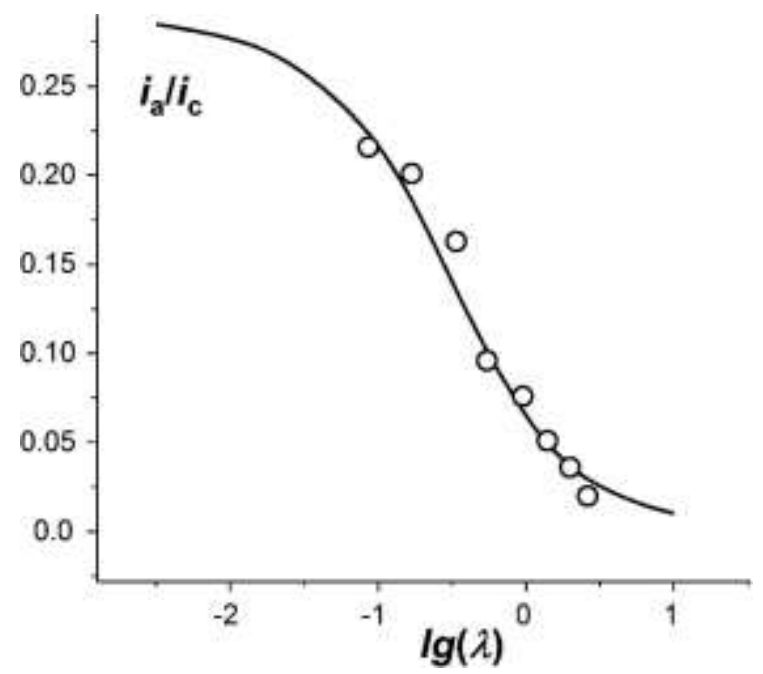


Figure 7. Dependence of $i_{\mathrm{a}} / i_{\mathrm{c}}$ ratio on $\lg (\lambda)$ for CA of $1\left(20 \mathrm{mmol} \mathrm{L} \mathrm{L}^{-1}\right)$ in $\mathrm{DMF} / 0.1 \mathrm{M} \mathrm{Bu}_{4} \mathrm{NClO}_{4}$. Experimental (circles) and simulated for mechanism (1, 3-5) (line). For simulation parameters, see Section 2.3.

\section{$1 \stackrel{9}{ }+\mathrm{PhOH} \rightleftharpoons 1^{\bullet}(\mathrm{PhOH})$}

\section{$1^{-*}(\mathrm{PhOH})+1^{\bullet-}(\mathrm{PhOH}) \rightleftharpoons 2^{2-}(2 \mathrm{PhOH})$}

\section{$2^{2-}(2 \mathrm{PhOH}) \longrightarrow 2+2 \mathrm{PhO}^{-}$}

One can see (Figs 6 and 8) that in contrast to sequence $(1,3-5)$, mechanism $(1,7-9)$ adequately describes the electroreduction of $\mathbf{1}$ in phenol-containing solutions in the conditions of cyclic voltammetry. The obtained equilibrium constant of reaction $(7)\left(K_{7}\right)$ has the same order of magnitude as those observed [50] for the complexes of $\mathrm{PhOH}$ with organic anions.

The disagreement between the mechanisms of reduction of $\mathbf{1}$ revealed by $\mathrm{CV}$ and CA can be explained by different near-electrode concentrations of the intermediate products in these methods. In order to check over this hypothesis, we analyzed the concentration profiles of dimer products formed under the conditions of CV and CA via the mechanisms $(1,3-5)$ and $(1,6-9)$ (Fig. 9 and 10). An inversed feature was indeed found for the formation of $\mathbf{2}$ in two methods. Figures 9 and 10 show that mechanism (1,6-9) dominates under conditions of $\mathrm{CV}$ when in case of CA the contribution of each mechanism varies over time, and mechanism $(1,3-5)$ prevails at $\mathrm{t}>0.5 \mathrm{~s}$. 


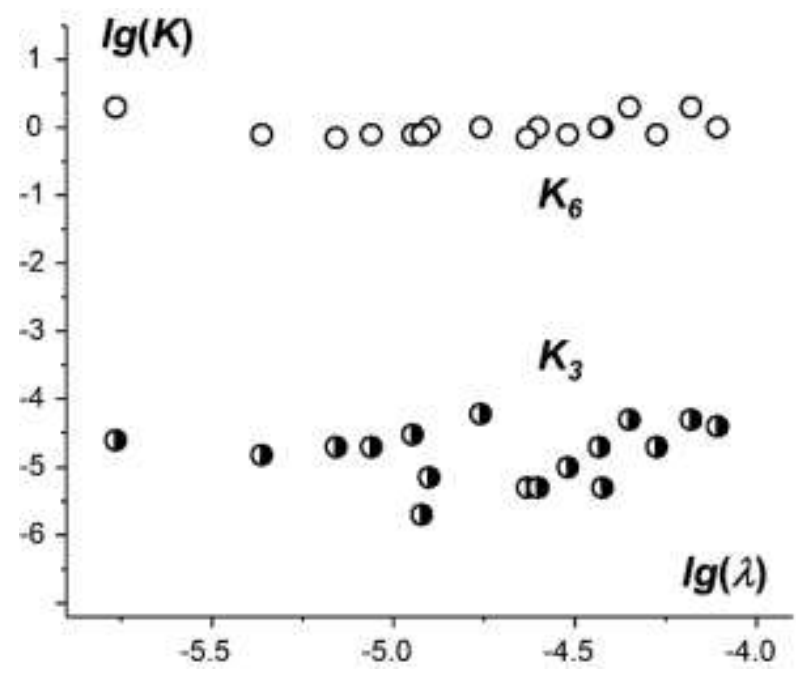

Figure 8. Equilibrium constants determined from $C V$ data: $K_{3}$ for mechanism (1,3-5) (half-filled circles), and $\mathrm{K}_{6}$ for mechanism (1, 7 - 9) (hollow circles).

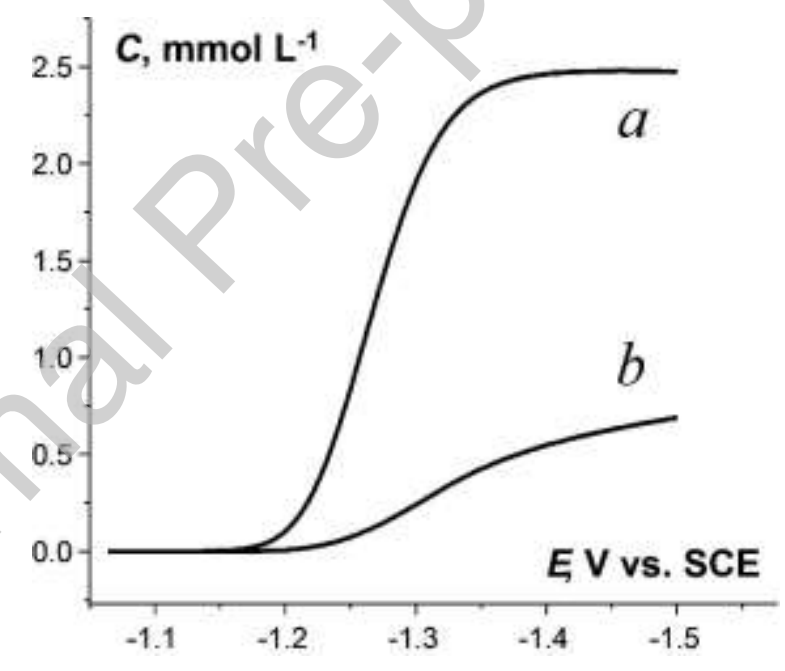

Figure 9. Evolution of surface concentration of $\mathbf{2}$ during the scan of potential in CV for two mechanisms: $(1,7-9)$ (a) and (1, 3-5) (b). 


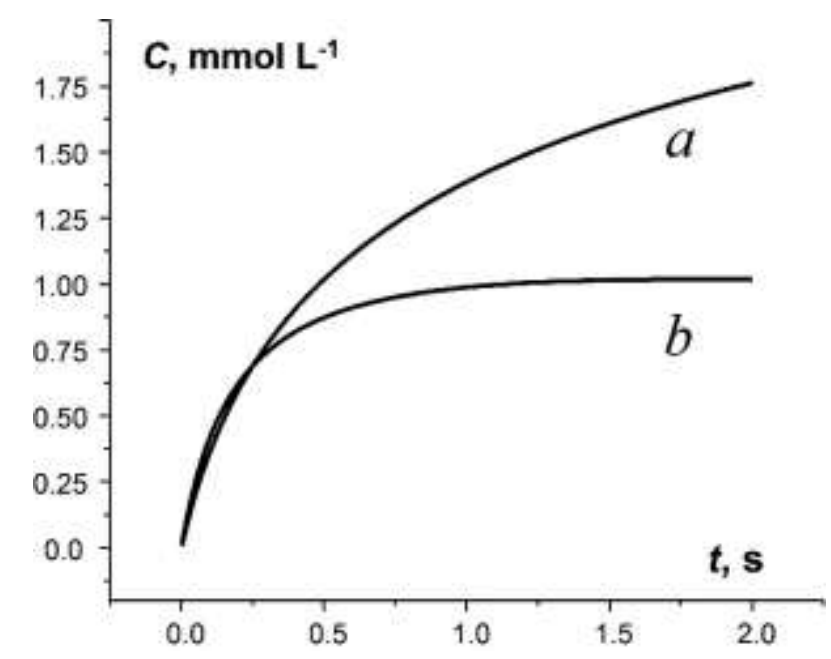

Figure 10. Evolution of surface concentration of 2, formed at the limiting current potential through the mechanisms $(1,3-5)$ (a) and $(1,7-9)$ (b) under the conditions of chronoamperometry.

Another promising method for preventing the dissociation of the dimer dianion $\mathbf{2}^{2-}$ might be involving it in the reactions of nucleophilic displacement with appropriate electrophilic substrates. Compared to C-electrophilic reagents most often used for alkoxide alkylation (AlkX, dimethylsulphate, dimethylcarbonate, methyl triflate, methoxymethyl ether etc [52, 53]), halosilanes are generally more reactive due to the pronounced Lewis acidity of silicon [54] and its high affinity to oxygen [55]. Besides this, using haloalkanes for $\mathrm{S}_{\mathrm{N}} 2$ alkylation of anion radicals raises the issue of single electron transfer interfering with the main process [56]; this factor is less important in the case of halosilanes given their more negative reduction potentials $[57,58]$. Reducing ability of anion radical $\mathbf{1}^{-\bullet}$, formed at $-1.40 \mathrm{~V}$, is supposedly not strong enough to provide a sufficient driving force for the efficient $\mathrm{ET}$ to $\left(\mathrm{CH}_{3}\right)_{3} \mathrm{SiCl}$ or $\left(\mathrm{CH}_{3}\right)_{2} \mathrm{SiCl}_{2}$ (with $\mathrm{E}_{\text {red }} \cong-3.20 \ldots-2.80 \mathrm{~V}$ vs $\mathrm{SCE}[58-60], \Delta \mathrm{E}_{\text {(substrate-mediator) }}>-1.40 \mathrm{~V}$ ). Therefore, trapping the dianion $\mathbf{2}^{2-}$ was attempted using these two chlorosilanes.

Electroreduction of $\mathbf{1}$ in the presence of $\left(\mathrm{CH}_{3}\right)_{3} \mathrm{SiCl}$ was carried out with an excess of the chlorosilane (2.5 times) with both substances simultaneously loaded. Provided a large excess of 
$\left(\mathrm{CH}_{3}\right)_{3} \mathrm{SiCl}$ over the electrogenerated nucleophilic form of fluorenone $\left(\mathbf{1}^{-\bullet}\right.$ or $\left.\mathbf{2}^{2-}\right)$ during the electrolysis, the silylation step can be considered as occurring at a maximal rate in a pseudo-firstorder regime.

Shortly after setting the working potential $\left(E \leq\left|E_{\text {red }}(\mathbf{1})\right|\right)$, the solution turned green from mixing colors of 1 (yellow) and $\mathbf{1}^{\bullet}$ (blue). If the hypothetical dimerization of similar to $\mathbf{3}^{\bullet}$ silylated radicals had not consumed them all, they would have been immediately reduced at the applied potential. Indeed, assuming (as in the case of protonation of $\mathbf{1}^{-\bullet}$ ) that the reduction potential of a silylated fluorene radical is less negative than $\mathrm{E}_{\mathrm{red}}(\mathbf{1})$ (set as the electrolysis potential), such radical species could not persist in the solution and be responsible for the observed blue coloration. This implies that $\mathbf{1}^{\bullet}$ remained in the solution even in the presence of an excess of $\left(\mathrm{CH}_{3}\right)_{3} \mathrm{SiCl}$. Moreover, GC-MS monitoring of the electrolysis did not show the formation of 9trimethylsiloxo-9H-fluorene (silylated monomer of fluorene) even in a trace amount. This suggests as well ruling out direct silylation of the anion radical $\mathbf{1}^{-\bullet}$ and ensuing reduction of the silylated radical to a silylated anion that would be protonated during the workup to give this product. Both arguments favor dianion $\mathbf{2}^{2-}$ to be the active nucleophilic species of silylation.

The only O-silylated product, 9,9'-bis[(trimethylsilyl)oxy]-9H,9'H-9,9'-bifluorene (Fig. 11), was formed in a practically quantitative yield ( $96 \%$ by GC-MS, $84 \%$ isolated). The product has Zconfiguration when the two C-O bonds are eclipsed. This is in line with higher stability of an eclipsed than a staggered conformation in "clamped" polyarylethanes $[61,62]$ that was observed, in particular, for 9,9'-bifluorenes [63]. Note that the formation of a -O-SiMe $-\mathrm{O}-$ bridged bifluorene, when $\left(\mathrm{CH}_{3}\right)_{2} \mathrm{SiCl}_{2}$ was used as an electrophile, also corroborates this feature. 


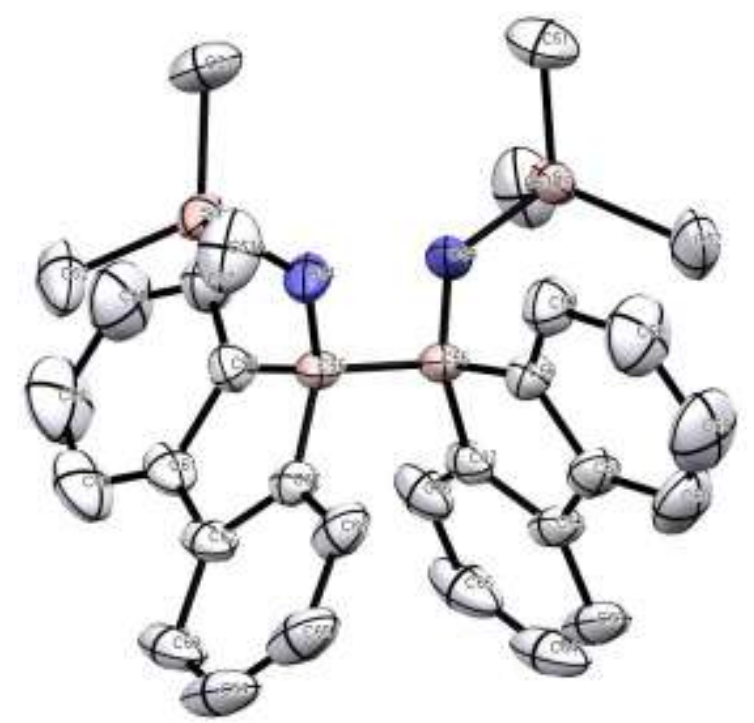

Figure 11. ORTEP drawing of 9,9'-bis[(trimethylsilyl)oxy]-9H,9'H-9,9'-bifluorene. Selected bond lengths $(\AA)$ and angles (degrees): C(55)-C(55') 1.569(4), C(55)-O(54) 1.414(3), $\angle \mathrm{O}(54)$ $\mathrm{C}(55)-\mathrm{C}\left(55^{\prime}\right) \quad 105.9, \angle \mathrm{Si}(3)-\mathrm{O}(54)-\mathrm{C}(55) \quad 134.4, \angle \mathrm{O}(54)-\mathrm{C}(55)-\mathrm{C}\left(55^{\prime}\right)-\mathrm{O}\left(54^{\prime}\right)-61.1, \angle \mathrm{C}(62)-$ $\mathrm{C}(67)-\mathrm{C}(55)-\mathrm{O}(54) 123.7, \angle \mathrm{C}(56)-\mathrm{C}(55)-\mathrm{C}\left(55^{\prime}\right)-\mathrm{C}\left(56^{\prime}\right) 174.8$ and $\angle \mathrm{C}(67)-\mathrm{C}(55)-\mathrm{C}\left(55^{\prime}\right)-\mathrm{C}\left(67^{\prime}\right)$

52.0. Thermal ellipsoids are shown with $50 \%$ probability, hydrogen atoms are omitted for clarity.

Addition of silicophilic co-reagents (HMPA, DMF or else of catalytic amounts of $\mathrm{F}^{-}$[63]), used to enhance the electrophilic reactivity of $\mathrm{Si}$ in chlorosilanes via the formation of a pentacoordinate transient [64], had no visible effect neither on the yield nor on selectivity of silylation. Interestingly, when using $\left(\mathrm{CH}_{3}\right)_{2} \mathrm{SiCl}_{2}$ as an electrophile for trapping $\mathbf{2}^{2-}$, the formation of molecular silylated product was not so smooth: some polymer silylated products were formed along with fluorene, 9,9'-bifluorene and 9,9'-bifluorenylidene. This is probably caused by the fact that $\left(\mathrm{CH}_{3}\right)_{2} \mathrm{SiCl}_{2}$ can react with two nucleophiles, which is possible either in a monomolecular (to give cyclic target product) or in an intermolecular (polymer products) manner. Therefore, avoiding an excess of the electrophile at any given moment of the electrolysis would supposedly favor intramolecular nucleophilic displacement in the chlorosilylated dimer anion. The origin of 
the non-silylated products also needs to be clarified. This work is under the progress and will be presented elsewhere.

\section{Conclusion}

In the case of the reversible nature of dimerization of the electrogenerated anion radicals of carbonyl compounds, high yields of pinacol-type products of electroreduction can be attained using proton donors and electrophiles whose acidity and electron affinity, respectively, are not sufficient for protonation of the anion radicals or for accepting an electron from them.

\section{Author statement}

Andrey Mendkovich: Conceptualization, Supervision, Formal analysis Arona Ngom: Investigation, Vladimir Kokorekin: Investigation, Mikhail Mikhailov: Software, Diariatou Gningue-Sall: Validation, Data curation, Viatcheslav Jouikov Writing - Review \& Editing, Visualization, Data curation

\section{Conflict of interest}

The authors declare that there is no conflict of interest with any financial organization regarding the material discussed in the manuscript. 


\section{References}

[1] R. Fittig, Jus. Lieb. Ann. Chem. 110 (1859) 23-45.

[2] A.S. Mendkovich, V. N. Leibzon, S.G. Mairanovski, M.M. Krayushkin, T.A. Klimova, S.S. Novikov, V.V. Sevost'yanova, Bull. Acad. Sci. USSR, Div. Chem. Sci. 27 (1978) 1639-1643.

[3] T.J. Curphey, C.W. Amelotti, T.P. Layloff, R.L. McCartney, J.H. Williams, J. Am. Chem. Soc. 91 (1969) 2817-2818.

[4] M. Schwientek, S. Pleus, C.H. Hamann, J. Electroanal. Chem. 461 (1999) 94-101.

[5] N. Egashira, T. Minami, T. Kondo, F. Hori, Electrochim. Acta. 31 (1986) 463-466.

[6] N.R. Armstrong, R.K. Quinn, N.E. Vanderborgh, Anal. Chem. 46 (1974) 1759-1764.

[7] N. Egashira, Y. Takita, F. Hori, Bull. Chem. Soc. Jap. 55 (1982) 3331-3332.

[8] V.P. Gul'tyai, A.S. Mendkovich, T.Ya. Rubinskaya, Bull. Acad. Sci. USSR, Div. Chem. Sci. 36 (1987) 1455-1458

[9] V.P. Gul'tyai, T. Ya. Rubinskaya, A.S. Mendkovich, A.I. Rusakov, Bull. Acad. Sci. USSR, Div. Chem. Sci. 36 (1987) 2609-2611.

[10] A.S. Mendkovich, A.P. Churilina, A.I. Rusakov, V.P. Gul'tyai, Bull. Acad. Sci. USSR, Div. Chem. Sci. 40 (1991) 1572-1577.

[11] V.P. Gul'tyai, T.Ya. Rubinskaya, A.S. Mendkovich, Bull. Acad. Sci. USSR, Div. Chem. Sci. 40 (1991) 372-375.

[12] T.Y. Rubinskaya, A.S. Mendkovich, N.K. Lisitsina, I.P. Yakovlev, V.P. Gul'tyai, Russ. Chem. Bull. 42 (1993) 1658-1661.

[13] A.S. Mendkovich, V.P. Gultyai, J. Electroanal. Chem. 169 (1984) 1-7. 
[14] A.S. Mendkovich, A.I. Rusakov, J. Electroanal. Chem. 209 (1987) 43-56.

[15] A.I. Rusakov, A.S. Mendkovich, V.P. Gul'tyai, V.Yu. Orlov, Structure and Reactivity of Organic Radical Anions, Mir, Moscow, 2005, p. 133 (in Russian).

[16] J.M.A. Empis, J.H. Bernardo, J. Chem. Soc., Perkin Trans. 2, 3 (1986) 425 - 430.

[17] A.S. Mendkovich, M.A. Syroeshkin, M.N. Mikhailov, D.V. Ranchina, A.I. Rusakov, Russ. Chem. Bull., 62 (2013) 1668-1670.

[18] A.S. Mendkovich, M.A. Syroeshkin, D.V. Nasybullina, M.N. Mikhailov, V.P. Gultyai, M.N. Elinson, A.I. Rusakov, Electrochim. Acta. 191 (2016) 962-973.

[19] A.S. Mendkovich, M.A. Syroeshkin, K.R. Mitina, M.N. Mikhailov, V.P. Gultyai, V.M. Pechennikov, Mendeleev Commun. 27 (2017) 580-582.

[20] G.M. Sheldrick, Acta Cryst. A71 (2015) 3-8.

[21] A.J. Bard, L.R. Faulkner, Electrochemical Methods: Fundamentals and Applications (2 ${ }^{\text {nd }}$ ed.), Wiley, 2001, p. 158.

[22] M.V. Mirkin, A.J. Bard, Anal. Chem. 64 (1992) 2293-2302

[23] A.S. Mendkovich, M.A. Syroeshkin, D.V. Ranchina, M.N. Mikhailov, V.P. Gultyai, A.I. Rusakov, J. Electroanal. Chem. 728 (2014) 60-65.

[24] Inorganic and Organometallic Polymers with Special Properties, R.M. Lain (Ed.). NATO ASI Ser. Ser. E, Kluwer Academic Publishers, Dordrecht, The Netherlands, 1992.

[25] E. J. Luis, G. Urry, Tetrahedron Lett. 29 (1968) 3295-3297.

[26] A.S. Mendkovich, D.V. Nasybullina, M.N. Elinson, L. V. Mikhalchenko, J. Electrochem. Soc. 167 (2020) 155502. 
[27] L. Nadjo, J.M. Saveant, J. Electroanal. Chem. 48 (1973) 113-145.

[28] C. Costentin, J.M. Saveant, J. Electroanal. Chem. 564 (2004) 99-113.

[29] A. Mendkovich, M. Syroeshkin, K. Mitina, M. Mikhailov, V. Gultyai, and V. Pechennikov, Mend. Commun., 27, 580 (2017).

[30] C.R. Wilke, Pin Chang, AIChE Journal. 1 (1955) 264-270.

[31] B.-G. J. Manuel, A. Guzmán-López, A. Cabrales-Torres, A. Estrada-Baltazar, G.A. IglesiasSilva. JCED 53 (2008) 1024-1027.

[32] R.L. Wang, Y.T. Kin., R.G. Compton. J. Electroanal. Chem. 434 (1997) 105-114.

[33] H. Kojima, A.J. Bard, J. Am. Chem. Soc. 97 (1975) 6317-6324.

[34] A.D. Becke, J. Chem. Phys. 98 (1993) 5648-5652.

[35] C. Lee, W. Yang, R.G. Parr, Phys. Rev. B, 37 (1988) 785-789.

[36] S.H. Vosko, L. Wilk, M. Nusair, Can. J. Phys. 58 (1980) 80-159.

[37] Gaussian 03, Revision B.03, M. J. Frisch, G. W. Trucks, H. B. Schlegel, G. E. Scuseria, M. A. Robb, J. R. Cheeseman, J. A. Montgomery, Jr., T. Vreven, K. N. Kudin, J. C. Burant, J. M. Millam, S. S. Iyengar, J. Tomasi, V. Barone, B. Mennucci, M. Cossi, G. Scalmani, N. Rega, G. A. Petersson, H. Nakatsuji, M. Hada, M. Ehara, K. Toyota, R. Fukuda, J. Hasegawa, M. Ishida, Cross, C. Adamo, J. Jaramillo, R. Gomperts, R. E. Stratmann, O. Yazyev, A. J. Austin, R. Cammi, C. Pomelli, J. W. Ochterski, P. Y. Ayala, K. Morokuma, G. A. Voth, P. Salvador, J. J. Dannenberg, V. G. Zakrzewski, S. Dapprich, A. D. Daniels, M. C. Strain, O. Farkas, D. K. Malick, A. D. Rabuck, K. Raghavachari, J. B. Foresman, J. V. Ortiz, Q. Cui, A. G. Baboul, S. Clifford, J. Cioslowski, B. B. Stefanov, G. Liu, A. Liashenko, P. Piskorz, I. Komaromi, R. L. Martin, D. J. Fox, T. Keith, M. A. Al-Laham, C. Y. Peng, A. Nanayakkara, M. Challacombe, P. 
M. W. Gill, B. Johnson, W. Chen, M. W. Wong, C. Gonzalez, and J. A. Pople, Gaussian, Inc., Pittsburgh PA, 2003.

[38] Gaussian 09, Revision A.02, M. J. Frisch, G. W. Trucks, H. B. Schlegel, G. E. Scuseria, M. A. Robb, J. R. Cheeseman, G. Scalmani, V. Barone, B. Mennucci, G. A. Petersson, H. Nakatsuji, M. Caricato, X. Li, H. P. Hratchian, A. F. Izmaylov, J. Bloino, G. Zheng, J. L. Sonnenberg, M. Hada, M. Ehara, K. Toyota, R. Fukuda, J. Hasegawa, M. Ishida, T. Nakajima, Y. Honda, O. Kitao, H. Nakai, T. Vreven, J. A. Montgomery, Jr., J. E. Peralta, F. Ogliaro, M. Bearpark, J. J. Heyd, E. Brothers, K. N. Kudin, V. N. Staroverov, R. Kobayashi, J. Normand, K. Raghavachari, A. Rendell, J. C. Burant, S. S. Iyengar, J. Tomasi, M. Cossi, N. Rega, J. M. Millam, M. Klene, J. E. Knox, J. B. Cross, V. Bakken, C. Adamo, J. Jaramillo, R. Gomperts, R. E. Stratmann, O. Yazyev, A. J. Austin, R. Cammi, C. Pomelli, J. W. Ochterski, R. L. Martin, K. Morokuma, V. G. Zakrzewski, G. A. Voth, P. Salvador, J. J. Dannenberg, S. Dapprich, A. D. Daniels, O. Farkas, J. B. Foresman, J. V. Ortiz, J. Cioslowski, and D. J. Fox, Gaussian, Inc., Wallingford CT, 2009.

[39] M.N. Mikhailov, N.D. Chuvylkin, I.V. Mishin, L.M. Kustov, Russ. J. Phys. Chem. A. 83 (2009) 752-755.

[40] J. Tomasi, M. Persico, Chem. Rev. 94 (1994) 2027-2094.

[41] E. Cances, B. Mennucci, J. Tomassi, J. Chem. Phys. 107 (1997) 3032-3041.

[42] V. Barone, M. Cossi, J. Phys. Chem. A 102 (1998) 1995-2001.

[43] G. Scalmani, M.J. Frisch, J. Chem. Phys. 132 (2010) 114110.

[44] N. Hirota, J. Chem. Phys. 37 (1962) 1884-1885.

[45] H. Tachikawa, H. Murai, H. Yoshida, H., Chem. Soc. Faraday Trans., 89 (1993) 23692373. 
[46] A.G. Davies, A.G. Neville, J. Chem. Soc., Perkin Trans. 22 (1992) 163-169.

[47] M.J. Hazelrigg, A.J. Bard, A.J., J. Electrochem. Soc. 122 (1975) 211-220.

[48] M.D. Ryan, D.H. Evans, J. Electroanal. Chem. 67 (1976) 333-357.

[49] F. Maran, D. Celadon, M.G. Severin, E. Vianello, J. Am. Chem. Soc. 113 (1991) 93209329.

[50] F.G. Bordwell, R.J. McCallum, W.N. Olmstead, J. Org. Chem. 49 (1984) 1424-1427.

[51] V.D. Parker, Acta. Chem. Scand. B. 37 (1983) 393-401.

[52] T.W. Green, P.G.M. Wuts, Protective Groups in Organic Synthesis ( $3^{\text {rd }}$ Ed.), John Wiley \& Sons, New York, 1999, p. 708.

[53] M. Selva, E. Militello, M. Fabris, Green Chem. 10 (2008) 73-79.

[54] S. N. Tandura, M. G. Voronkov, N.V. Alekseev, Top. Curr. Chem. 131 (1986) 99-189.

[55] R. Beserra, R. Walsh, In: Z. Rappoport, I. Apeloig (Eds), The Chemistry of Organic Silicon Compounds, Wiley, Chichester, UK, 1998, V. 2, Ch. II, p. 153.

[56] J.M. Saveant, Elements of Molecular and Biomolecular Electrochemistry, WileyInterscience, New York, 2006, p. 239.

[57] S. Soualmi, M. Dieng, A. Ourari, D. Gningue-Sall, V. Jouikov, Electrochim. Acta, 158 (2015) 457-469.

[58] V. Jouikov, C. Biran, M. Bordeau, J. Dunogues, J. Electrochim. Acta, 45/7 (1999) 10151024.

[59] C. Biran, M. Bordeau, D. Bonafoux, D. Deffiieux, C. Duprat, V. Jouikov, M. LegerLambert, C. Moreau, F. Serein-Spirau, J. Chim. Phys. 93 (1996) 591-600. 
[60] V. Jouikov, C. Bernard, C. Degrand, New J. Chem. 23 (1999) 287-290.

[61] H.H. Huang, Aust. J. Chem. 29 (1976) 2415-2422.

[62] G.A. Olah, L.D. Field, M. Watkins, R. Malhotra, J. Org. Chem. 46 (1981) 1761-1764.

[63] A.R. Basindale, P.G. Taylor, Reaction Mechanisms of Nucleophilic Attack at Silicon, In: S.

Patai, Z. Rappoport (Eds.), The Chemistry of Organic Silicon Compounds, John Wiley \& Sons, 1989, p. 840.

[64] R.J. Corriu, Hypervalent Species of Silicon: Structure and Reactivity, In: A.R. Bassindale, P.P. Gaspar (Eds.), Frontiers of Organosilicon Chemistry, RSC, Cambridge, 1991. 